\title{
Indian Women in the Workplace
}

\section{Dr. Arundhati Bhattacharyya}

\author{
Assistant Professor, Department of Political Science, B. G. College, Kolkata, West Bengal, India
} bhattacharyya.arundhati4@gmail.com

\section{Doi:10.5901/mjss.2015.v6n4s2p118}

\begin{abstract}
Indian working women have treaded difficult paths to make a place of their own in their workplaces. Today, there are women achievers in each field. The social reformers of the past had played an important role in spreading education to empower women. The Constitution of India has provided positive discriminations for women. The Indian State has passed several laws and implemented policies to improve their condition. But, still, Indian women today face visible and invisible discriminations in their path. Working women even today have problems regarding inadequate and unclean toilets, sexual harassment in the workplace, unsafe roads, etc. This paper tries to paint a picture about the steps taken to improve the condition of women in the pre-independence period, international situation, role of the Indian State and the judiciary and the recommendations which may ease some of the problems faced by working women. Affirmative measures have attempted to narrow the gap between the two genders in the workplace, but much needs to be done. The paper is based on secondary sources.
\end{abstract}

Keywords: Indian Women, discrimination, Constitution, State, Rights

\section{Introduction}

India is the largest democracy in the world which believes in the principle of social justice. It is a welfare State, which tries to provide the best services to the maximum population. India is a country of paradox. On the one hand, in India, worshipping of goddesses is common; on the other hand, crime against women has spiralled up. The lower status of women is evident both in the public and private spaces. Indian women can be called the largest subaltern in the Indian society. They are the largest minority in the society. Barring few exceptions, Indian women vis-à-vis Indian men are discriminated against in the workplace or in the homes. Disparity in the private space is reflected in the public space also. Population of Indian women, according to the 2011 census is 586.5 million. The sex ratio is 940 females to 1000 males, which is a matter of concern.

According to Gender Gap Index 2013, share of women in non-agricultural sector is 18 percent of total nonagricultural employment. Share of women on boards of listed companies is 7 percent and firms with female participation in ownership is 9 percent. ${ }^{1}$ According to the report of the International Labour Organization's Global Employment Trends, 2013, India's labour force participation rate for women was 29 in 2009-2010. Out of 131 countries with available data, India ranks 11th from the bottom in female labour force participation.(Begum 2013) The number of women in India's workforce fell from 28.7 per cent in 2004-05 to 22.8 per cent in 2009-10, and even further to 21.9 per cent in 2011-12, according to the latest report from National Sample Survey Office (NSSO) (Bhattacharya 2013)Gender discrimination, glass ceiling, sexual harassment in the workplace, lop-sided gender parity etc have become hurdles in the path of working women in several places.

Traditionally, in India, women have been identified with the private space and the public space was the hunting ground of men. In exceptional situations, ordinary Indian women treaded into the public space. The public/private space has always been influenced by patriarchal socialization and domination. (Chari 2009) Though Indian history provides innumerable situations, where women have played significant role in turning the wheels of history, but, still, Indian women had to prove time and again their own mettle. They have been pushed to being second-class citizens even in their homes, regarding availability of food, access to education, decision-making rights etc

Scenario has slowly improved in India with the rising level of education and increasing awareness about the need to have a just society. Women are better placed today, in the workplace compared to their position in the earlier centuries. But, even today, the monopoly of positions in government and private sectors are manned by men. There may be some exceptional women in the top levels, but they are still exceptions today. Although more women are working, they

${ }^{1}$ http://reports.weforum.org/global-gender-gap-report-2013/\#section=country-profiles-india(March 2015) 
are often still worse paid than men, in part-time jobs or in the huge informal employment sector with little protection and few rights. The situation is not much different from the global scenario, where, even Sheryl Sandberg of Facebook had to comment that women are not making it to the top of any profession in the world. Women who are in powerful positions often find they face a daily barrage of sexist behaviour from men. (Gaag 2014) Gender gap exists in workplaces. In Asia and elsewhere, the economic crisis has brought women towards greater difficulties. Women in informal sector suffered more regarding employment and wages. ${ }^{2}$ In India, also, successful women have to prove themselves doubly to remove the obstacles in their path. The initiative by individual has been supported by attempts undertaken by the Indian judiciary and the Parliament to create a harassment-free environment in the workplace.

The objectives of the study are to understand the prevailing position of Indian women in general; to study the role of the Indian State in empowering women, in general and in the workplace and to analyze the areas of concern confronted by working women.

The paper is based on secondary sources, like books, journal articles, newspaper articles etc. This paper provides a commentary on the position of Indian women in workplace. It tries to provide a critical and analytical picture of the position of Indian women in the workplace.

\section{India in the Past}

Indian social reformers, like Raja Rammohan Roy and Ishwar Chandra Vidyasagar, have always supported rights of women who have been the most vulnerable group in British India. Reform movements had started in the early $19^{\text {th }}$ century. It was universally recognised that the proper sphere of a woman's activities was the home and she was not required to take any interest in public or national affairs, which were exclusively the concern of men. But, even during the colonial rule, women's education was gaining support from the social reformers of the age. An educated mother can be a better guide to her children as her awareness level will be high. It will help the future generations to advance. The Calcutta Congress of 1917 presided over by Mrs. Besant supported votes for women. Special session of the Indian National Congress in 1918 passed by three-fourths majority passed a resolution in favour of women's suffrage. The Muslim League also followed suit by a resolution in favour of franchise for Indian women. So, the two major parties supported the voting rights of women. (Khera 1942) Slowly, education of girls was becoming a priority for a section of the educated class. It was realized even by radical reformers, like JyotibaPhule, that education of a woman was the need of the hour to fulfil the duties of a supportive wife and a doling mother who can positively shape the child's life. It was the middle class and the upper-middle class who started getting their children educated. During the freedom struggle against the British, Gandhiji legitimised the strength of the 'feminine' qualities in his fight against violence. Women became visible in the mass movement against the colonial rule. The contribution of women in the struggle for freedom played a constructive role in strengthening the position of Indian women in the public space. Women got assurance and an array of democractic rights through the Indian Constitution. (Chari 2009)

\section{International Situation}

Equality of rights for women is a basic principle of the United Nations. At Philadelphia, in 1944, the International Labor Conference adopted a Declaration. It proclaimed that "all human beings, irrespective of race, creed or sex, have the right to pursue both their material well-being and their spiritual development in conditions of freedom and dignity, of economic security and equal opportunity". Women workers' rights constitute an integral part of the values, principles and objectives that are at the core of the International Labor Organization's mandate to promote social justice and decent work, which is fairly paid, productive work carried out in conditions of freedom, equity, security and dignity. ${ }^{3}$ Two important Instruments of the International Labor Organization are Resolution on Gender Equality, Pay Equity and Maternity Protection, adopted in 2004 and a decision of the ILO's Governing Body in March 2005. It has made gender mainstreaming obligatory in all the ILO's technical cooperation activities. It has been reinforced in the 2006 International Labor Conference Resolution.

The United Nations Convention on the Elimination of All Forms of Discrimination against Women (CEDAW) was

${ }^{2}$ Women in Asia: Underpaid, undervalued and underemployed.(1999) World Of Work: Magazine of the ILO - No. 32, 6 http://www.ilo. org/wcmsp5/groups/public/---dgreports/-dcomm/documents/publication/dwcms_080623.pdf( February 2015)

${ }^{3}$ ABC of Women Workers' Rights And Gender Equality (2007)(2nd ed.)Geneva: International Labour Organization http://www.ilo.org/ wcmsp5/groups/public/---dgreports/---gender/documents/publication/wcms_087314.pdf (March 2015) 
adopted in 1979 by the UN General Assembly. It came into force in 1981. The State Parties' have specific obligations to eliminate discrimination and remove obstacles in the path of women's enjoyment of their rights in law and in practice. ${ }^{4}$ It has often been referred as the 'international Bill of Rights' for women. It provides the key principles of equality between men and women, prohibits discrimination against women on any ground, and covers many aspects of women's rights including political participation, health, education, employment, marriage, family relations and equality before the law. The Commission on the Status of Women has played an important role in promoting women's rights. It has prepared recommendations relating to urgent problems in the field of women's rights with the object of implementing the principle that men and women should have equal rights, and the development of proposals to give effect to such recommendations. ${ }^{5}$ Conventions on Equal Remuneration between Women and Men, 1951, Discrimination (Employment and Occupation) Convention, 1958; Workers with Family Responsibilities Convention, 1981; Elimination of the worst forms of child labour, 1999, Part-time workers, 1994 and Home workers, 1996, Maternity Protection Convention, 2000, termination of employment, 1982, and employment policy, 1964 are instruments for protecting rights of women. ${ }^{6}$ All these instruments have helped women in empowering them. Women are also entering the labor force in record numbers. (Kelly 1980)

\section{Role of the Indian State}

Indian State has been playing a role of 'benevolent father'. India had got independence from colonial rule with lot of support from the women-folk. The Indian Constitution has not discriminated against women. Certain affirmative discrimination has been ennumerated in the Indian Constitution in support of women. In the Eighth Five Year Plan, a shift has been seen from 'development' to 'empowerment'of women. Part III of the Indian Constitution deals with the Fundamental Rights. Rights have been provided to Indian girls and women to bloom fully and sharpen their personality. The Constitution-Makers had tried their utmost to provide the maximum enforceable rights for the Indians. The Supreme Court and the High Courts have increased the limits of these rights. Part IV of the Indian Constitution provides nonjusticiable rights called the Directive Principles of State Policy. These are mostly socio-economic rights. Article 14 guarantees equality before law and equal protection of the laws. Arts 15(1) and (3), 16(4), 32, 226, 39(a) and (d), 42, 46, 47, $243 \mathrm{D}$ (3), $243 \mathrm{D}$ (4), $243 \mathrm{~T}$ (3), $243 \mathrm{~T}$ (4) are some of the provisons which have supported the rights of women workers. The writs of Habeas Corpus, Mandamus, Certiorari, Prohibition and Quo Warranto have been quite effective. Article 39 of Constitution envisages that the State shall direct its policy, among other things, towards securing that there is equal pay for equal work for both men and women.

The Government of India has enacted several laws like Special Marriage Act, 1954; Hindu Marriage Act, 1955; Hindu Succession Act, 1956; Hindu Minority and Guardianship Act, 1956; Hindu Adoption and Maintenance Act, 1956; Immortal Traffic Prevention Act, 1956; Dowry Prohibition Act, 1961 and 1984; Maternity Benefit Act, 1961 ; Medical Termination of Pregnancy Act, 1971 ; Child Marriage Restraint (Amendment) Act, 1978; Family Court Act, 1984; Indecent Representation ofWomen (Prohibition) Act, 1986; Commission of Sati (Prevention) Act, 1987 etc, in order to improve the overall condition of the Indian women. The publication of Towards Equality Report in 1974 has been a watershed for focussing on the needs of the women in India. The National Plan of Action for Women, 1976; National Perspective Plan for Women, 1988; Shramashakti, 1988; National Commission for Women, 1990; Support to Training and Employment Programme for Women, 1987; Rashtriya Mahila Kosh; Mahila Samridhi Yojana; Indira Awaas Yojana; Jawahar Rozgar Yojana; Streeshakti Mission; Development of Women and Children in Rural Areas; Training Rural Youth for Self Employment; National Rural Health Mission; National Rural Employment Guarantee-Scheme; the 73rd and 74th Constitutional Amendment Acts of 1993 and the support services launched and effectualized by the Government of India prove the emerging desire and preparedness of the State of India to facilitate empowerment of women in India. (Misra 2006) Maternity Benefits Act, 1961 has also helped many. The object of maternity leave and benefit is to protect the dignity of motherhood by providing for the full and healthy maintenance of women and her child when she is not working. With the advent of modern age, as the number of women employees are growing, the maternity leave and other facilities

\footnotetext{
${ }^{4}$ Equality And Women's Economic, Social And Cultural Rights: A Guide to Implementation and Monitoring Under the International Covenant on Economic, Social and Cultural Rights,(2004)University of Minnesota Minneapolis: International Women's Rights Action Watch, http://www1.umn.edu/humanrts/iwraw/CESCRMANUAL.pdf (March 2015)

${ }^{5}$ Short History of CEDAW Convention United Nations, United Nations Entity for Gender Equality and the Empowerment of Women Department of Public Information http://www.un.org/womenwatch/daw/cedaw/history.htm( February 2015)

${ }^{6} A B C$ of Women Workers' Rights And Gender Equality (2007)( 2nd ed.)Geneva: International Labour Organization http://www.ilo.org/ wcmsp5/groups/public/---dgreports/---gender/documents/publication/wcms_087314.pdf (March 2015)
} 
have become important. ${ }^{7}$ The judiciary through its interpretation has increased the scope of the rights. In Municipal Corporation of Delhi vs. Female Workers (2000) case, the judiciary held that the maternity leave to women workers is in consonance with the Directive Principles of State Policy contained in Arts 19, 42 and 43 of the Constitution of India. It entitles maternity leave even to women engaged on casual basis or on muster roll basis on daily wages and not only those in regular employments. This happened after union of female workers who were not on regular rolls, but were treated as temporary workers and employed on Muster roll, claimed that they should also get maternity benefit like regular workers.

Equal Remuneration Act, 1976 has opened the doors to many Indian women which implemented Article 39 of the Indian Constitution. Prior to the Act the President of India promulgated on the 26th September, 1975, the Equal Remuneration Ordinance, 1975. 1975 was celebrated as the International Women's Year.Equal Remuneration Act, 1976 supports payment of remuneration at equal rates to men and women workers and other matters. It is the duty of the employer to pay equal remuneration to men and women workers for same work or work of similar nature. No discrimination should be made while recruiting men and women workers. ${ }^{8}$ The law states that no discrimination is permissible in recruitment and service conditions except where employment of women is prohibited or restricted by the law. In India, the implementation of the Equal Remuneration Act, 1976 is done at two levels. In the Central sphere, the enforcement is entrusted to the Chief Labour Commissioner who heads the Central Industrial Relations Machinery. The Central Government has appointed Labour Enforcement Officers as Inspectors for the purpose of making investigation of implementation of the provisions of the Equal Remuneration Act, 1976 by the employers. In case of employments provided by the State Government, the enforcement is done by the officials of the State Labour Department. The Central Government also monitors the implementation of the provisions of the Equal Remuneration Act, 1976 by the State Governments. ${ }^{10}$ According to many critics, Equal Remuneration Act in India seeks to determine wages on the basis of a politically motivating or social justice related factor, in this case, gender. Implementation of the law is difficult as the law enforcement agencies are either inactive, or corrupt. ${ }^{11}$

The Employees State Insurance Act, 1948 has brought in provisons of Employees' State Insurance Corporation and medical benefits. In spite of stability and uniformity in the medical treatment given to the insured persons, a great leeway requires to be made so far as facilities for hospitalisation, adequate facilities for specialist services and proper treatment to T.B. patients are concerned. (Mehta 1961) Welfare of women workers has been supported by The Factories Act, 1948, The Mines Act, 1952, The Plantation Labour Act, 1951, The Beedi and Cigar Workers (Conditions of Employment) Act, 1966, The Contract Labour (Regulation and Abolition) Act, 1970, The Inter-state Migrant Workmen (Regulation of Employment and Conditions of Service) Act, 1979, Building and Other Construction Workers' (Regulation of Employment and Conditions of Service) Act, 1996, Minimum Wages Act, 1948, Payment of Wages Act, 1936, The Employees' State Insurance Act, 1948, The Workmen Compensation Act, 1923, The Employees Provident Funds and Miscellaneous Provisions Act, 1952 and Payment of Gratuity Act, $1972 .{ }^{12}$

The Government of India has also set up Women Labour Cell. It is a separate Cell for women labour which was set up in 1975, is functioning in the Ministry to pay special attention to the problems of women labour. Ministry of Women and Child Development is the nodal department on ccordinating aspects regarding women labour. It works in conjunction with Ministry of Women and Child Development. It implements Equal Remuneration Act. It sets up Advisory Committee for promotion of employment of women under the Equal Remuneration Act, 1976 and providing secretariat assistance to the Committee. It also follows up action on the Supreme Court Judgement in the matter of prevention of sexual harassment of women at their work place and periodical reviews of the initiatives taken in the matter in consultation with related agencies like National Commission for Women, Ministry of Women and Child Development, National Labour Institute, etc. The Cell is also administering a grants-in-aid Scheme for providing financial assistance to voluntary and non-government organizations for taking up action programmes/projects for the benefit of women labour. The Ministry is also running a Grant-in-aid Scheme for the welfare of women labour since Sixth Five Year Plan (1981-82). It is administered through voluntary organizations by giving grant-in-aid to them for oganizing working women and educating them about their

TMaternity Benefits Act, 1961 (53 of 1961)[12th December, 1961http://www.medindia.net/indian_health_act/maternity-benefit-act-1961introduction.htm (January 2015)

${ }^{8} \mathrm{http}: / /$ pblabour.gov.in/pdf/acts_rules/equal_remuneration_act_1976.pdf (March 2015)

${ }^{9}$ Subramanian, L. V. 'Working Women Labour Laws' http://indianlabour.org/index.php/labour-laws-institutes/labour-laws/working-womenlaws/ (February 2015)

${ }_{10}$ http://labour.gov.in/content/division/equal-remuneration.php (March 2015)

${ }_{11}^{11}$ Kavarana, Aditi, Equal Remuneration Act. Centre for Civil Society,http://ccs.in/equal-remuneration-act(March 2015)

12 'Women's Rights And Labour Statutes', http://shodhganga.inflibnet.ac.in/bitstream/10603/12832/13/14_chapter\%205.pdf(February 2015) 
rights/duties, legal aid to working women and organizing seminars, workshops, etc. aiming at raising the general consciousness of the society about the problems of women labour.13

Indian women workers had been facing sexual harassment at workplace, but they got the legal support initially by Vishakha Guidelines of the Supreme Court and later by the Sexual Harassment of Women at Workplace (Prevention, Prohibition and Redressal) Act, 2013. Employers are liable to pay a fine of Rs 50,000 for failing to implement the provisions of the Sexual Harassment of Women at Workplace (Prevention, Prohibition and Redressal) Act. ${ }^{14}$ Sexual harassment at workplace is slowly been recognized as serious crime. Complaints are increasing in the workplace. There were 700 complaints which were registered in the Karnataka Labour Commssioner's office. (Sarpotdar 2013) A safe environment in the workplace is a right of every working woman.

The Judiciary in India has played an important role through pronounced judgements and activism in protecting rights of Indian women. The Supreme Court and the High Courts have increased the arena of overall rights for women in India. This judicial legislation filled in the gap in the existing legal scenario. The Supreme Court provided equal rights of Hindu girls and woman on property along with other male relatives for any partition made in intestate succession after September 2005. The Court added "According to the new Section 6, the daughter of a coparcener becomes a coparcener by birth in her own rights and liabilities in the same manner as the son. The declaration in Section 6 that the daughter of the coparcener shall have same rights and liabilities in the coparcenary property as she would have been a son is unambiguous and unequivocal". ${ }^{15}$ The Supreme Court in 2014 removed the discrimination against women make-up artists in the film industry in India. The Court stated that it would not allow the "constitutionally impermissible discrimination"16 existing in the film industry.

In India, the private sector is also making extra effort to improve the working condition of women. For example, the tech companies are making an all-out effort to retain women in their workplace. They have initiated the work-from-home, flexi-timing options, special cabs for would-be-homes, creche facilities etc. The companies have recognized that flexi time or work-from-home as options can be options to include employee productivity and retention. Initiative has been taken where employees can donate their unused vacation time to their colleagues who are in need of additional paid leave to attend to critical medical or personal matters. (Phadnis\& John 2003)

In 2013, the Ministry of Women and Child Development passed a resolution to "provide and promote crèche and day care facilities for children of working mothers, mothers belonging to poor families, ailing mothers and single parents." ${ }^{\text {17 }}$ Rajiv Gandhi National Crèche Scheme for Children of Working Mothers currently covers tribal, rural and urban children across 449 districts and has benefitted many working mother. An onsite childcare facility is an incentive for working women because women get to work full time and take care of the child because the mother can see the child a few times in the day. Child care centres can be a support-base for working mothers who can both successful personal and professional lives. The guilt factor of the working mother can be decreased many times with better child care facilities. ${ }^{18}$

Though the number of women in Indian workplace is increasing, the toilet facilities are not keeping pace. The presence of women in higher levels has improved the number of toilets in some places compared to the earlier years. Many working women in India have faced inadequate, badly designed, poorly maintained and sometimes completely nonexistent toilet facilities. The situation is improving slowly with the Government of India taking on sanitation as an important issue. The state government of Maharashtra has ordered that all commercial establishments need to provide separate toilets for women staff, or face penalties and even criminal action. (Doctor 2014) Adequate restrooms and washrooms where women do not need to queue up for long stretches of time need to be maintained. ${ }^{19}$ These are basic necessities

\footnotetext{
${ }^{13}$ http://mau.nic.in/Departments/labour/LWPGuideline.pdf(March 2015)

${ }^{14}$ 'Rs 50,000 fine for violation of sexual harassment law: Maneka Gandhi' March19, 2015http://indianexpress.com/article/india/indiaothers/rs-50000-fine-for-violation-of-sexual-harassment-law-maneka/(February 2015)

15 Hindu woman entitled to equal property rights: Supreme Court(2011) http://www.thehindu.com/news/national/hindu-woman-entitled-toequal-property-rights-supreme-court/article2534751.ece (March 2015)

${ }^{16}$ Anand, Utkarsh, Supreme Court says Women can be Make-Up Artists.(2014) http://indianexpress.com/article/india/india-others/scsays-women-can-be-make-up-artists/( February 2015)

17 How Creches At Indian Offices Can Empower More Women To Work.http://www.womensweb.in/2014/07/more-creches-at-indianoffices/ (March 2015)

${ }^{18}$ 'She wants to change the way women work in India'

http://www.rediff.com/getahead/report/career-she-wants-to-change-the-way-women-work-in-india/20141010.htm( February 2015)

19'Women and the Perfect Workplace',http://www.accenture.com/Microsites/vaahini/slice-of-life/Pages/women-and-the-perfect-workplace. aspx( February 2015)
} 
which were non-existent. Indian women felt ashamed even to voice their sanitation needs earlier due to social norms. But, now working women are not hesitating in demanding their basic rights.

Another issue among working women in India is lack of safety on the roads. The lurking fear of crime decreases the efficiency of the worker. Women do feel vulnerable after repeated incidents of crime against women in India on the roads. It has also created fears in the minds of family members. (Dutta 2012) Many parents have tried to persuade their daughters to leave jobs which have irregular working hours. The government machinery has increased its steps to thwart crimes against women, but the fear of returning home from workplace for Indian women has affected their output.

\section{Recommendations}

Initiative to improve the working condition of women workers in India has been taken at various levels, by both the State and private agencies. Federation of Indian Chambers of Commerce and Industry (FICCI) and FICCI Ladies Organization have provided some recommendations for improvement of safety of women at workplace. Some of them are installation of electronic doors allowing access to the work area only to authorized employees, security guard or a colleague to accompany the driver in the cab, if a woman staff working in a night shift is either the first to be picked up or last to be dropped, Global Positioning System based monitoring of transport vehicles with panic buttons, mobile applications to be installed on employee phones for increased tracking and safety measures, well-lit work areas, staircases and parking lots till the last woman employee leaves the site, separate and secure toilets for women close to their work station, strict surveillance of visitors, security staff and drivers to be employed only after police verification, 24x7 transport helpdesk for drivers \& staff /family members with dedicated emergency cab on standby for exigencies, to have a code of conduct agreement in place to be affirmed annually by employees and vendors with clear defining behavioural norms especially for males with female employees, setting up of a sexual harassment committee reporting to the managing director or a senior member of the management and headed by a woman etc ${ }^{20}$

Just like women in the private companies, the Government of India has also provided safeguards and recommendations to make women employees comfortable in their workplace. For example, special incentives have been given to women to join the para-military forces. Some of them are-

a. 'Creches' and 'Day Care Centres' have been provided to women employees.

b. Separate accommodation for women personnel with basic amenities.

c. Toilet facilities are made available for the use of women employees by pitching of proper tents with commode in areas where appropriate locations are not available.

d. Vehicles fitted with mobile toilets for women personnel during movement from one place to another and during picketing duties.

e. Facilities already available under the Central Government like Maternity Leave, Child Care Leave, are also applicable to para-military women personnel.

f. Medical facilities with special care to the pregnant women

g. Lady Doctors are available to provide medical coverage.

h. Education facilities to their children in KendriyaVidyalaya have been provided wherever available.

i. Facilities have been provided to women personnel at par with their male counter parts at work place without any gender bias.

j. In case of married women, generally husband and wife are posted in same station as far as possible.

k. Women personnel are given equal opportunity in their career progression i.e. promotion/seniority at par with male counter parts.

I. Women personnel are encouraged to be self-dependent by imparting proper training and talks during various courses. ${ }^{21}$

\section{Conclusion}

Affirmative action measures and skills development initiatives will enhance the socio-economic position of a sizeable

${ }^{20}$ SafetyOf Women At The Workplace: Recommendations for Businesses, Recommendations by FICCI \& FLO Industry Task Force On Safety Of Women At Work Place http://www.ficci.com/SEdocument/20249/Safety-of-women-at-workplaces-Recommendations-forBusinesses.pdf (February 2015)

${ }_{21}$ 'Percentage Of Women In Paramilitary Forces,'(2013) RajyaSabhaUnstarred Question No.992, Ministry Of Home Affairs, New Delhi: Government Of India, http://mha1.nic.in/par2013/par2013-pdfs/rs-140813/992.pdf(February 2015) 
portion of women in the coming years, in order to narrow the gap between formal equality and substantive equality. (Grant 2005) Rights of Indian women in the workplace are connected to the overall condition of women in the Indian society. Assertion of rights is also necessary from the end of the Indian women in the workplace. Gender mainstreaming has varied benefits which the world has recognized. Men and women are not identical, but the concept of equity should be given importance in addressing the differences between the genders. Women should have a decent working condition so that they can voice their problems. The Indian State has introduced many reforms aiming at social justice. It is the society which needs to amend its attitude towards working women. Successful working women in the country have proved to be role models to others through their achievements. But, it depends on the individual girl or woman to change each hurdle in ones life into victory towers. The suggested steps will also pep up the happiness index of India.

\section{References}

ABC of Women Workers' Rights And Gender Equality (2007)( $2^{\text {nd }}$ ed.)Geneva: International Labour Organization http://www.ilo. org/wcmsp5/groups/public/---dgreports/---gender/documents/publication/wcms_087314.pdf (March 2015)

Anand, Utkarsh, Supreme Court says Women can be Make-Up Artists.(2014) http://indianexpress.com/article/india/india-others/sc-sayswomen-can-be-make-up-artists/( February 2015)

Begum, AnjumanAra, (2013) India: No redress for sexual harassment at the work place. http://www.humanrights.asia/news/ahrcnews/AHRC-ART-146-2013 (February 2015)

Bhattacharya, Suryatapa, (2013) Women waning in India's workforce. http://www.thenational.ae/news/world/south-asia/women-waningin-indias-workforce (March 2015)

Chari, Anurekha, (2009) Gendered Citizenship and Women's Movement. Economic and Political Weekly, 44, 47-57 http://www.jstor. org/stable/40279185 (February 2015)

Doctor, Vikram, (2014) Number of women in workforce on the rise, but toilet facilities for them not keeping pace, http://articles. economictimes.indiatimes.com/2014-08 23/news/53139461_1_women-staff-toilet-all-male((March 2015)

Dutta, Aesha, (2012) Working women across India feel the lurking danger.http://www.thehindubusinessline.com/news/working-womenacross-india-feel-the-lurking-danger/article4238483.ece (March 2015)

Equality And Women's Economic, Social And Cultural Rights: A Guide to Implementation and Monitoring Under the International Covenant on Economic, Social and Cultural Rights,(2004)University of Minnesota Minneapolis: International Women's Rights Action Watch, http://www1.umn.edu/humanrts/iwraw/CESCRMANUAL.pdf (March 2015)

Gaag, Nikki van der, (2014) Women are better off today, but still far from being equal with men. The Guardian, http://www.theguardian. com/global-development/2014/sep/29/women-better-off-far-from-equal-men

Grant, Brenda (2005) Beyond Beijing: Women's Rights in the Workplace. Agenda: Empowering Women for Gender Equity, Beyond Beijing, 64, 90-98. http://www.jstor.org/stable/4066576, (August 2014) http://www.thehindubusinessline.com/news/workingwomen-across-india-feel-the-lurking-danger/article4238483.ece (March 2015)

Hindu woman entitled to equal property rights: Supreme Court(2011) http://www.thehindu.com/news/national/hindu-woman-entitled-toequal-property-rights-supreme-court/article2534751.ece (March 2015)

How Creches At Indian Offices Can Empower More Women To Work.

http://www.womensweb.in/2014/07/more-creches-at-indian-offices/ (March 2015)

http://reports.weforum.org/global-gender-gap-report-2013/\#section=country-profiles-india(March 2015)

http://mau.nic.in/Departments/labour/LWPGuideline.pdf(March 2015)

http://pblabour.gov.in/pdf/acts_rules/equal_remuneration_act_1976.pdf(March 2015)

Kavarana, Aditi, Equal Remuneration Act. Centre for Civil Society,http://ccs.in/equal-remuneration-act(March 2015)

Kelly, Janis, Women in the Workplace. (1980) Off Our Backs, 10, 8

http://www.jstor.org/stable/25773217( August 2014)

Khera, P. N., (1942) Civic Rights Of Women In British India. The Indian Journal of Political Science, 4, 35- 63 Stable http://www.jstor. org/stable/42743008. (August 2014)

Maternity Benefits Act, 1961 (53 of 1961)[12th December, 1961http://www.medindia.net/indian_health_act/maternity-benefit-act-1961introduction.htm (January 2015)

Mehta, Usha, (1961), The Working Of The Employees' State Insurance Scheme In India: An Aspect Of Centre-State Relations. The Indian Journal of Political Science, 22, 205-213 http://www.jstor.org/stable/41853882 . (January 2015)

Misra, Jugal Kishore,(2006) Empowerment Of Women In India. The Indian Journal of Political Science, 67, 867-878 http://www.jstor. org/stable/41856270 . (February 2015)

'Percentage Of Women In Paramilitary Forces,'(2013) RajyaSabhaUnstarred Question No.992, Ministry Of Home Affairs, New Delhi: Government Of India, http://mha1.nic.in/par2013/par2013-pdfs/rs-140813/992.pdf(February 2015)

Phadnis, Shilpa, and John, Sujit, (2003) Bangalore Inc woos women. http://timesofindia.indiatimes.com/city/bengaluru/Bangalore-Incwoos-women/articleshow/18921570.cms (February 2015)

'Rs 50,000 fine for violation of sexual harassment law: Maneka Gandhi' March 19, 2015http://indianexpress.com/article/india/indiaothers/rs-50000-fine-for-violation-of-sexual-harassment-law-maneka /(February 2015)

Safety Of Women At The Workplace: Recommendations for Businesses, Recommendations by FICCI \& FLO Industry Task Force On 
Safety Of Women At Work Place http://www.ficci.com/SEdocument/20249/Safety-of-women-at-workplaces-Recommendationsfor-Businesses.pdf (February 2015)

Sarpotdar, Anagha, (2013) Sexual Harassment of Women: Reflections on the Private Sector. Economic \& Political Weekly, xlvlil, 18-19.

'She wants to change the way women work in India' http://www.rediff.com/getahead/report/career-she-wants-to-change-the-way-womenwork-in-india/20141010.htm( February 2015)

Short History of CEDAW Convention United Nations, United Nations Entity for Gender Equality and the Empowerment of Women Department of Public Information http://www.un.org/womenwatch/daw/cedaw/history.htm( February 2015)

Subramanian, L. V. Working Women Labour Laws. http://indianlabour.org/index.php/labour-laws-institutes/labour-laws/working-womenlaws/ (February 2015) http://labour.gov.in/content/division/equal-remuneration.php( February 2015)

'Women and the Perfect Workplace',http://www.accenture.com/Microsites/vaahini/slice-of-life/Pages/women-and-the-perfect-workplace. aspx( February 2015)

Women in Asia: Underpaid, undervalued and underemployed.(1999) World Of Work: Magazine of the ILO - No. 32, 6 http://www.ilo. org/wcmsp5/groups/public/---dgreports/-dcomm/documents/publication/dwcms_080623.pdf( February 2015)

Women's Rights AndLabour Statutes. http://shodhganga.inflibnet.ac.in/bitstream/10603/12832/13/14_chapter\%205.pdf (February 2015) 